\title{
Phytochemical content, antioxidant activity and mineral elements of honey produced by four different species of Malaysian stingless bees
}

\author{
${ }^{1}$ Maringgal, B., ${ }^{1,4, *}$ Hashim, N., ${ }^{2}$ Tawakkal, I.S.M.A., ${ }^{3}$ Mohamed, M.T.M. and \\ ${ }^{1}$ Hamzah, M.H. \\ ${ }^{1}$ Department of Biological and Agricultural Engineering, Faculty of Engineering, Universiti Putra \\ Malaysia, 43400 Serdang, Selangor, Malaysia. \\ ${ }^{2}$ Department of Process and Food Engineering, Faculty of Engineering, Universiti Putra Malaysia, 43400 \\ Serdang, Selangor, Malaysia. \\ ${ }^{3}$ Department of Crop Science, Faculty of Agriculture, Universiti Putra Malaysia, 43400 Serdang, Selangor, \\ Malaysia. \\ ${ }^{4}$ SMART Farming Technology Research Centre, Faculty of Engineering, Universiti Putra Malaysia, 43400 \\ Serdang, Selangor, Malaysia.
}

\section{Article history: \\ Received: 10 April 2020 \\ Received in revised form: 10 \\ June 2020 \\ Accepted: 22 September 2020 \\ Available Online: 3 January \\ 2021}

\section{Keywords:}

Malaysian stingless bee honey

Total flavonoid content,

Total phenolic content,

Antioxidant

Mineral elements

DOI:

https://doi.org/10.26656/fr.2017.5(S1).006

\begin{abstract}
This study investigated the phytochemical composition of honey from four species of Malaysian stingless bee i,e. Tetragonula laeviceps, Geniotrigona thoracica, Lepidotrigona terminata, as well as Heterotrigona itama. The measured phytochemical composition was total phenolic content (TPC), total flavonoid content (TFC), antioxidant activity, $\mathrm{pH}$, colour intensity, and mineral element analysis i.e. Magnesium (Mg), Calcium (Ca), Zinc $(\mathrm{Zn})$, Potassium $(\mathrm{K})$, and Sodium $(\mathrm{Na})$. The production of honey by the L. terminata had the highest TPC value $(6.74 \pm 0.57 \mathrm{mg} \mathrm{GAE} / 100 \mathrm{~g} \mathrm{FW})$ while the $T$. laeviceps possesses the highest TFC value $(14.85 \pm 3.71 \mathrm{mg} \mathrm{QE} / 100 \mathrm{~g} \mathrm{FW})$. In the antioxidant activity measurement, honey from the H. itama obtained the highest percentage of 1,1-diphenyl-2picrylhydrazyl (DPPH) inhibition $(29.52 \pm 0.45 \%)$ and honey from $T$. laeviceps displayed the highest value in the Ferric reducing antioxidant power (FRAP) analysis $(0.95 \pm 0.013$ abs). The four distinct stingless bee species' colour intensity demonstrated the variation of colour intensity in the range of 0.09-0.23 abs mAU. All honey obtained the $\mathrm{pH}$ values (4.75-5.03) within the acidic medium. $\mathrm{Mg}$ is the major mineral element in all honey samples which is followed by $\mathrm{Na}, \mathrm{Ca}, \mathrm{K}$, and $\mathrm{Zn}$.
\end{abstract}

\section{Introduction}

Honey is a supersaturated sugar solution containing beneficial natural remedy that is popular for food and medicinal usage. It comes from the plant's floral nectar part which is being converted into honey using the enzymes produced by the bees (Cantarelli et al., 2008). Da Silva et al. (2013) reported that honey contains 80$85 \%$ carbohydrates, $15-17 \%$ water, $0.3 \%$ protein, and $0.2 \%$ ashes. The authors added that honey contains high fructose and glucose concentration, and low amino acids, minerals, organic acids, phenolic acids, vitamins, enzymes, and other phytochemicals levels.

Recently, studies on stingless bee honey gained wide attention in Malaysia. Stingless bee honey is sugary liquid, superb in taste, and odour (Chuttong et al., 2016). Biluca et al. (2014) explained that the stingless bee honey has various phytochemical content as opposed to regular honey bee in terms of colour, taste, water, viscosity, and sugar contents. Moreover, stingless bee honey has a greater content of polyphenols and flavonoids as compared to the honey that is produced by Apis spp. (Rodriguez-Malaver et al., 2009; RodriguezMalaver et al., 2013; Biluca et al., 2016). In addition, Maringgal et al. (2019) indicated that stingless bee honey from six regions in Malaysia has significant variation in its phytochemical content in terms of total phenolic content (TPC), total flavonoid content (TFC), antioxidant activity, colour intensity, and $\mathrm{pH}$. The authors also found that the phytochemical content has a significant correlation with the botanical and geographical regions in Malaysia. A seminal study in this area is the work of Lim et al. (2019) who explained that the stingless bee honey's nutritional value is also 
affected by environmental, storage condition, and processing factors. Due to the excellent phytochemical content and the nutritional benefits, this honey was valued by consumers globally, that renders it commercially more valuable (Da Silva et al., 2013). This also explained that the stingless bee honey's selling price can go up to $\$ 100 / \mathrm{kg}$, which is almost twice the price of the honey bee $(\$ 20-40 / \mathrm{kg})$ (Shadan et al., 2018).

Honey is also rich with mineral elements which represent its therapeutic value. Plant uptake from the soil and the environment from where the bees gather the nectar in the process of producing honey determine the mineral elements in it (Alves et al., 2013; Alqarni et al., 2014). Kek et al. (2017) reported that Malaysian raw honey contains high elements of potassium, sodium, and calcium. The authors added that the mineral element is higher for honey harvested from the forest or jungle when compared with honey that collected from farm plantation. Although there are 32 species of stingless bee that had been documented in Malaysia (Norowi et al., 2010), studies on phytochemical content on the different stingless bee honey are still limited. This is supported by Kelly et al. (2014) who figure out that 17-32 stingless bee species are established in Malaysia, but only two species ( $H$. itama and $G$. thoracica) are largely being used in the meliponiculture and research studies. The knowledge on composition as well as mineral elements of stingless bee honey from Malaysia is also hardly found. The quality of stingless bee honey differed from the standards that are laid out by the international honey standards in terms of its composition (Codex Alimentarius Commission, 2001). Thus, the present study is carried out with the following objectives: 1) to determine the phytochemical content consist of TFC, TPC, colour intensity, antioxidant activity, and $\mathrm{pH}$ of four honey samples produced by four different species of Malaysian stingless bee; 2) to determine the mineral elements of honey produced by four different species of Malaysian stingless bee.

\section{Materials and methods}

\subsection{Preparation of Malaysia stingless bee honey samples}

One litre of honey samples from four different species (T. laeviceps, G. thoracica, L. terminata, and $H$. itama) of stingless bee was collected from the Stingless Bee Farm, Universiti Putra Malaysia during December 2017 to March 2018. All the samples were harvested from the stingless beehives located in multibotany nectar source. All the samples were placed at room temperature in sterile airtight glass bottles in order to prevent moisture absorption during the sampling duration, analytical test, and storage. For the purpose of assessing the total phenolic content (TPC), total flavonoid content
(TFC), $\mathrm{pH}$ values, colour intensity, and antioxidant capacity i.e. 1,1-diphenyl-2-picrylhydrazyl (DPPH) inhibition and Ferric reducing antioxidant power (FRAP) activities, approximately two grams of honey were diluted in $20 \mathrm{~mL}$ of distilled water whereby it produces the concentration of $0.1 \mathrm{~g} / \mathrm{mL}$. Meanwhile, for the mineral elements analysis, $0.5 \mathrm{~g}$ of honey samples was kept in a Tetrafluoromethaxil (TFM) vessel with $2 \mathrm{~mL}$ of hydrogen peroxide $(30 \% \mathrm{v} / \mathrm{v})$ and $3 \mathrm{~mL}$ of nitric acid $(65 \% \mathrm{v} / \mathrm{v})$. Each analysis was repeated four times.

\subsection{Phytochemical analysis}

TPC and TFC of honey were analysed using the aluminum chloride colorimetric technique (Ali et al., 2015) and the Folin-Ciocalteu reagent (Berretta et al., 2005). About $200 \mu \mathrm{L}$ of honey solution was added to 3 $\mathrm{mL}$ of $10 \%$ diluted Folin-Ciocalteu reagent. The absorbance was computed at $750 \mathrm{~nm}$ with the use of a Multiskan GO microplate spectrophotometer (Thermo Scientific 1510) after placing the solution in the dark at room temperature. The TPC value was stated as mg gallic acid equivalents per $100 \mathrm{~g}$ of honey.

To measure TFC, $2 \%$ of aluminium chloride solution was mixed with $1 \mathrm{~mL}$ of the honey sample (0.1-0.4 g/ $\mathrm{mL})$. The mixture's absorbance was calculated at $430 \mathrm{~nm}$ using a Multiskan GO microplate spectrophotometer (Thermo Scientific 1510) after incubating it for $10 \mathrm{mins}$ at $25^{\circ} \mathrm{C}$. Based on the quercetin standard, with the use of a calibration curve, TFC was expressed in mg QUE/ 100 g FW.

\subsubsection{Measurements of antioxidant activity}

\subsubsection{Inhibition of DPPH}

A specific sample's scavenging activity is measured in electron transfer, which is the principal of DPPH method (Garcia et al., 2012). Without direct exposure to light and at room temperature, the assay produces a constant concentrated violet solution. The honey's radical scavenging activity was determined via the use of Multiskan GO microplate spectrophotometer at $517 \mathrm{~nm}$ against the DPPH radical, as detailed out Beretta et al. (2005), in this research. The DPPH solution was prepared by dissolving $2 \mathrm{mg}$ of DPPH in $100 \mathrm{~mL}$ of ethanol. Following that, $2 \mathrm{~mL}$ of DPPH solution was mixed with $1 \mathrm{~mL}$ of ethanolic honey solution. The reaction mixture was vigorously shaken to yield a good mixture and then stored for half an hour at the room temperature without exposing it to light. Following that, the mixture's absorbance was recorded. The honey's scavenging activity through DPPH radical was calculated from the equation below:

DPPH radical scavenging activity $(\%)=\frac{(\text { Abscontrol }- \text { Abssample })}{\text { Ahs nnntrol }} \times 100$ 
Where Abs control refers to the DPPH radical and ethanol absorbance, and Abs sample refers to the DPPH radical, and honey or ascorbic acid absorbance. The experiment was carried out four times.

\subsubsection{FRAP analysis}

FRAP is a parameter that measures the reductant or antioxidant activity of a sample. The reduction of $\mathrm{Fe}^{3+}$ to $\mathrm{Fe}^{2+}$ indicates the total reduction (Yen and Duh, 1993; Ahmad and Abdullah, 2013). In this research, the FRAP analysis was carried out by adding $0.5 \mathrm{~g}$ honey and 100 $\mathrm{mL}$ distilled water into $2.5 \mathrm{~mL}$ of phosphate buffer (0.2M, pH 6.6) and $2.5 \mathrm{~mL}$ of $1 \%$ potassium ferricyanide. The mixtures were incubated for a total of 20 mins under $50^{\circ} \mathrm{C}$. After that, $2.5 \mathrm{~mL}$ of $10 \%$ trichloroacetic acid was added to the mixture $0.5 \mathrm{~mL}$ $0.1 \%$ ferric chloride and $1 \mathrm{~mL}$ distilled water were added to the $1 \mathrm{~mL}$ mixture. The rate at which the solution was absorbed was calculated at $700 \mathrm{~nm}$ through the use of a Multiskan GO microplate spectrophotometer (Thermo Scientific 1510). The honey's FRAP activity was expressed in absorbance unit.

\subsubsection{Measurements of $\mathrm{pH}$ and colour intensity}

The colour intensity representing honey's darkness value was measured using the method detailed out in the previous research (Beretta et al., 2005). With the use of warm water at 45 to $50^{\circ} \mathrm{C}$, a $50 \%(\mathrm{w} / \mathrm{v})$ honey solution was prepared. The net absorbance was obtained from the use of Multiskan GO microplate spectrophotometer at $450 \mathrm{~nm}$. The $\mathrm{pH}$ was measured with the use of a $\mathrm{pH}$ meter, model LAQUA twin pH (HORIVA, Japan).

\subsubsection{Measurements of mineral elements}

The mineral elements analysis was determined by using the method described by Kek et al. (2017). The TFM vessels with honey solutions were closed and later placed in the polypropylene rotor body, whereby this was later placed into a microwave digestor (MLS 1200 Mega, Milestone S.r.l., Sorisole, Bergamo, Italy) for the digestion process to take place. After digestion, the rotor body's temperature was brought down to room temperature. The sample digested was gathered and later diluted to $50 \mathrm{~mL}$ using deionised water for mineral analysis. Mineral elements of Magnesium (Mg), Sodium $(\mathrm{Na})$, Calcium $(\mathrm{Ca})$, Potassium $(\mathrm{K})$, and Zinc $(\mathrm{Zn})$ were determined with the use of the atomic absorption spectrometer (AAS) (GBC-906, GBC Scientific Equipment Pty. Ltd., Melbourne, Australia).

\subsection{Statistical analysis}

The analysis of significance between mean values were carried out using the one-way analysis of variance (ANOVA) and Tukey's multiple-comparisons analysis using SAS 9.4 software. The significant level was set to be $\mathrm{P} \leq 0.05$.

\section{Results and discussion}

\subsection{Total phenolic content (TPC) and total flavonoid content (TFC)}

The TPC as well as the TFC values of Malaysian stingless bee honey samples are depicted in Table 1. The outcomes revealed that the TPC and TFC values have significant difference $(\mathrm{P} \leq 0.05)$ among the species of stingless bee honey. The content of TPC found in honey samples ranged from 3.39 to $6.74 \mathrm{mg} \mathrm{GAE} / 100 \mathrm{~g} \mathrm{FW}$. Samples from the $G$. thoracica honey had the lowest values of TPC, while honey from the L. terminata showed the highest value. The analysis also indicated that the TPC value of honey from $T$. laeviceps $(5.52 \mathrm{mg}$ GAE/100 g) is significantly different with $G$. thoracica value of $3.39 \mathrm{mg}$ GAE/100 $\mathrm{g}$, but insignificantly different from $L$. terminata $(6.74 \mathrm{mg} \mathrm{GAE} / 100 \mathrm{~g})$ and $H$. itama (4.47 mg GAE/100 g).

The mean TFC constituent values of honey in four different ranged from 3.74 to $14.85 \mathrm{mg}$ QUE/100 $\mathrm{g} \mathrm{FW}$. Honey from the $T$. laeviceps demonstrated the highest TFC followed by the H. itama, L. terminata, and $G$. thoracica. The one-way ANOVA also showed the same trend with TPC value whereby the TFC of honey from $T$. laeviceps with $14.85 \mathrm{mg}$ QUE/100 $\mathrm{g} \mathrm{FW}$ is statistically significantly different with $G$. thoracica with the value of $3.74 \mathrm{mg}$ QUE/100 $\mathrm{g} \mathrm{FW}$, but no significant difference

Table 1. The TPC, TFC, antioxidant activities, colour intensity and $\mathrm{pH}$ in stingless bee honey from various species

\begin{tabular}{|c|c|c|c|c|c|c|}
\hline Species & $\begin{array}{c}\text { TPC } \\
(\mathrm{mg} \mathrm{GAE} / 100 \mathrm{~g} \\
\text { FW) } \\
\end{array}$ & $\begin{array}{c}\text { TFC } \\
\text { (mg QUE/100 g } \\
\text { FW) } \\
\end{array}$ & $\begin{array}{c}\text { DPPH } \\
(\%)\end{array}$ & $\begin{array}{c}\text { FRAP } \\
\text { (abs) }\end{array}$ & $\begin{array}{c}\text { Colour } \\
\text { Intensity } \\
(\mathrm{abs}, \mathrm{mAU}) \\
\end{array}$ & $\mathrm{pH}$ \\
\hline T. laeviceps & $5.52 \pm 0.56^{\mathrm{ab}^{*}}$ & $14.85 \pm 3.71^{\mathrm{a}}$ & $17.22 \pm 1.15^{\mathrm{b}}$ & $0.95 \pm 0.013^{\mathrm{a}}$ & $0.23 \pm 0.001^{\mathrm{a}}$ & $4.75 \pm 0.45^{\mathrm{a}}$ \\
\hline G. thoracica & $3.39 \pm 0.06^{\mathrm{c}}$ & $3.74 \pm 0.07^{\mathrm{b}}$ & $12.34 \pm 0.95^{\mathrm{c}}$ & $0.91 \pm 0.01^{\mathrm{b}}$ & $0.09 \pm 0.001^{\mathrm{c}}$ & $5.03 \pm 0.47^{\mathrm{a}}$ \\
\hline L. terminata & $6.74 \pm 0.57^{\mathrm{a}}$ & $9.98 \pm 0.71^{\mathrm{ab}}$ & $28.36 \pm 0.66^{\mathrm{a}}$ & $0.91 \pm 0.01^{\mathrm{ab}}$ & $0.18 \pm 0.01^{\mathrm{b}}$ & $4.95 \pm 0.53^{\mathrm{a}}$ \\
\hline H. itama & $4.47 \pm 0.10^{\mathrm{bc}}$ & $13.05 \pm 0.23^{\mathrm{a}}$ & $29.52 \pm 0.45^{\mathrm{a}}$ & $0.898 \pm 0.001^{b}$ & $0.23 \pm 0.002^{\mathrm{a}}$ & $4.85 \pm 0.44^{\mathrm{a}}$ \\
\hline
\end{tabular}

Values are expressed as mean \pm SD. Values with the same superscript letters within the same column are not significantly different at $\mathrm{P} \leq 0.05$ by using Tukey test. 
with L. terminata (9.98 $\mathrm{mg} \mathrm{QUE} / 100 \mathrm{~g} \mathrm{FW})$ and $H$. itama (13.05 mg QUE/100 g FW).

The different species of stingless bee honey could offer an explanation for the variation in TPC value. Similar researches were performed by Biluca et al. (2016) describing the TPC values from 10.3 to $98.0 \mathrm{mg}$ $\mathrm{GAE} / 100 \mathrm{~g}$ for ten different species of stingless bee honey from Santa Catarina, Brazil. Seminal contributions have been made by Silva et al. (2013) and Da Silva et al. (2013) found that the TPC values ranged from 1.30 to $66.00 \mathrm{mg}$ GAE$/ 100 \mathrm{~g}$ for stingless bee honeys from Amazon and Paraiba, Brazil. The current study also showed that the TFC of honey differ significantly between different stingless bee species. On the other hand, a study by Fadzilah et al. (2017) discovered the TFC of honey values ranged from 15.28 to $31.80 \mathrm{mg} / \mathrm{g}$ QE for three different stingless bee species in Malaysia; T. apicalis, T. itama, and T. thoracica.

Apart from different species, the TPC and TFC values of stingless bee honey are also affected by the geographical and botanical origins of the nectar gathered in producing the honey. Recently, Maringgal et al. (2019) revealed the TPC and TFC values of Malaysian stingless bee honey varied significantly among the geographical locations in Malaysia. These findings corroborate with the current studies by Majid et al. (2019), who showed the values of TPC and TFC of stingless bee honey produced by $H$. itama were influenced by the geographical floral origins in Johor, Malaysia.

\subsection{Antioxidant activity}

The honey samples' DPPH radical scavenging effect is depicted in Table 1. Stingless bee honey from H. itama had the greatest ability to scavenge DPPH radicals with the DPPH inhibition by $29.52 \%(\mathrm{P} \leq 0.05)$ followed by L. terminata, and T. laeviceps. Meanwhile, G. thoracica demonstrated the lowest value in DPPH inhibition of $12.34 \%$. The current study also indicated that the DPPH inhibition values showed statistically significant difference among the stingless bee species. However, there was no significant difference found in the DPPH inhibition values between honey that produced $L$. terminata and $H$. itama.

The finding seems to be consistent with Tuksitha et al. (2018) who found that DPPH assay content of the three different honeys produced by three stingless bees species (G. thoracica, H. itama, and H. erythrogastra) from Sarawak (Eastern of Malaysia) are ranging from $17.0 \pm 7.5 \%$ to $47.4 \pm 3.2 \%$. Whereas, Abu Bakar et al. (2017) found that H. itama honey collected in Melaka (Western of Malaysia) showed the highest DPPH assay

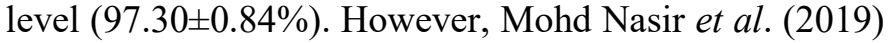
explained in contradict way where honey collected in Besut and Dungun, Terengganu that produced by $H$. itama, T. laeviceps, and G. thoracica species does not possess good antioxidant activity with the DPPH inhibition value were below than $50 \%$.

The values of DPPH inhibition in honey are always carried out a large variety of amount since the values depend on the botanical and geographical origin as well as the bee species (Boussaid et al., 2014; Habib et al., 2014). The difference in the species of stingless bee may explain the variations of DPPH inhibition values in current studies, even though the honey was collected at the same geographical origin. It was supported by Agus et al. (2019) who found that different geographical origins of meliponiculture influenced the antioxidant activity of honey produced by $T$. laeviceps species. The authors also added that antioxidant activity DPPH of $T$. laeviceps honey had a significant effect on TPC and TFC.

The average values of FRAP analysis (Table 1) of honey from the $H$. itama demonstrated the lowest antioxidant potential while the honey produced by $T$. laeviceps obtained the highest values $(\mathrm{P} \leq 0.05)$, depicting the highest reducing power of $\mathrm{Fe}^{3+}$. Surprisingly, no significant differences were found in the FRAP values of honey among the stingless bee species. However, the FRAP values of honey produced by $T$. laeviceps and $G$. thoracica have significant differences. These outcomes agree with those of Biluca et al. (2016) who found that different species of stingless bee showed significant differences in reducing the power of $\mathrm{Fe}^{3+}$. Moreover, the authors found that the honey sample produced by $M$. marginata species resulted in the utmost reducing power of $\mathrm{Fe}^{3+}(624 \mathrm{mmol} \mathrm{Fe} \mathrm{II/100} \mathrm{g)} \mathrm{and} \mathrm{the}$ lowest reducing power is found in the honey sample harvested from the M. bicolor species $(61.1 \mathrm{mmol} \mathrm{Fe}$ II/100 g)

\section{$3.3 \mathrm{pH}$ and colour}

Normally, stingless bee honey has sourness in taste and a distinct aroma due to their acidic nature. When compared to the Malaysia Standard (2017), the current study revealed the $\mathrm{pH}$ values ranged between $4.75-5.03$ (Table 1). The mean $\mathrm{pH}$ values from the $T$. laeviceps presented the lowest $\mathrm{pH}$ value while the $G$. thoracica species obtained the highest $\mathrm{pH}$ value $(\mathrm{P} \leq 0.05)$. These findings mirror those of the previous review by and Nordin et al. (2018) and Omar et al. (2019), who found that the $\mathrm{pH}$ of the stingless bee honey varies between 3.15 to 6.64 . This is supported by Maringgal et al. (2019) who revealed similar acidic value for stingless bee honey from Malaysia with the $\mathrm{pH}$ values ranged from 4.25 to 
5.5. Moreover, De Sousa et al. (2016) explained that the acidic value was corresponding to the balance of organic acid present in the honey, where the $\mathrm{pH}$ value varies and depends on the floral origin and the bee species. In addition, Ramón-Sierra et al. (2015) described that the $\mathrm{pH}$ value of honey is also affected by the fermentation of sugars to alcohol by microorganisms and being subjected to subsequent oxidation to carboxylic acids during storage. Suntiparapop et al. (2012) concluded that low $\mathrm{pH}$ value in $T$. laeviceps honey could contribute to their antimicrobial activity.

Bertoncelj et al. (2007) explained that colour is one of the physical observations that is related to the botanical origin, minerals, phenolic content, storage time, and temperature of the honey. The present study shows the value of colour intensity of honey produced by four different species of stingless bees ranged from 0.09$0.23 \mathrm{mAU}$ (Table 1). The colour intensity values from $T$. laeviceps and $H$. itama had the highest values followed by the L. terminata and G. thoracica $(\mathrm{P} \leq 0.05)$. Nevertheless, the ANOVA results showed that the colour intensity values are not statistically significant between the colour of honey produced by $T$. laeviceps and $H$. itama. However, there is a statistically significant difference for both species between the L. terminata and G. thoracica.

Similarly, Kek et al. (2014) also found the variations in colour intensity values of honey in different of bee species. Guerrini et al. (2009) described that the colour intensity of honey differs based on mineral content and pH. Meanwhile, Baretta et al. (2005) explained the variation of colour intensity of honey differs based on the geographical and the bee species. However, the colour intensity of honey also affected by a few factors like exposure to light, enzymatic reactions, and heat and storage time (De Sousa et al., 2016).

\subsection{Mineral elements}

Finola et al. (2007) described that honey has various mineral composition. In addition, the authors added that mineral elements in honey are directly related to the geographical, environmental, and botanical aspects of the area where the honey is being produced. Figure 1 illustrated the mean value of different mineral elements content in honey produced by four different stingless bee species. It can be observed that Magnesium $(\mathrm{Mg})$ is the most outstanding element in all analyses of honey, in which $G$. thoracica produced the highest $\mathrm{Mg}$ value at $83.02 \mathrm{mg} / \mathrm{kg}$. A seminal study by Biluca et al. (2016) also found that the element of $\mathrm{Mg}$ in the stingless bee honey from Brazil is within the range $0.410-17.3 \mathrm{mg} / 100$ g. This finding could be due to the different geographical location of the stingless bee to produce the honey. In a similar finding, Kek et al. (2017) claimed that the mean amount of $\mathrm{Mg}$ in honey that produced by $\mathrm{H}$. itama from Malaysia was $33.81 \mathrm{mg} / \mathrm{kg}$.

Sodium $(\mathrm{Na})$ is the second-largest mineral element that can be found in honey produced by four different stingless bee species ranging from $22.69-32.93 \mathrm{mg} / \mathrm{kg}$. Honey produced by $T$. laeviceps has relatively high $\mathrm{Na}$ $(32.93 \mathrm{mg} / \mathrm{kg})$ followed by L. terminata $(26.61 \mathrm{mg} / \mathrm{kg})$, G. thoracica $(24.78 \mathrm{mg} / \mathrm{kg})$, and lastly H. itama $(22.69$ $\mathrm{mg} / \mathrm{kg}$ ). Pohl (2009) explained that the variations of $\mathrm{Na}$ content in honey might be because of flying area, nectar collection, and plant selection from the bees to produce the honey. These are in line with the finding of Fuenmayor et al. (2013), which described that mineral elements in honey are contingent upon the bee species apart from the botanical and the geographical origin. In addition, the authors also found the differences of mineral elements from different stingless bee species in Colombia.

Calcium (Ca) is the third abundant element and the

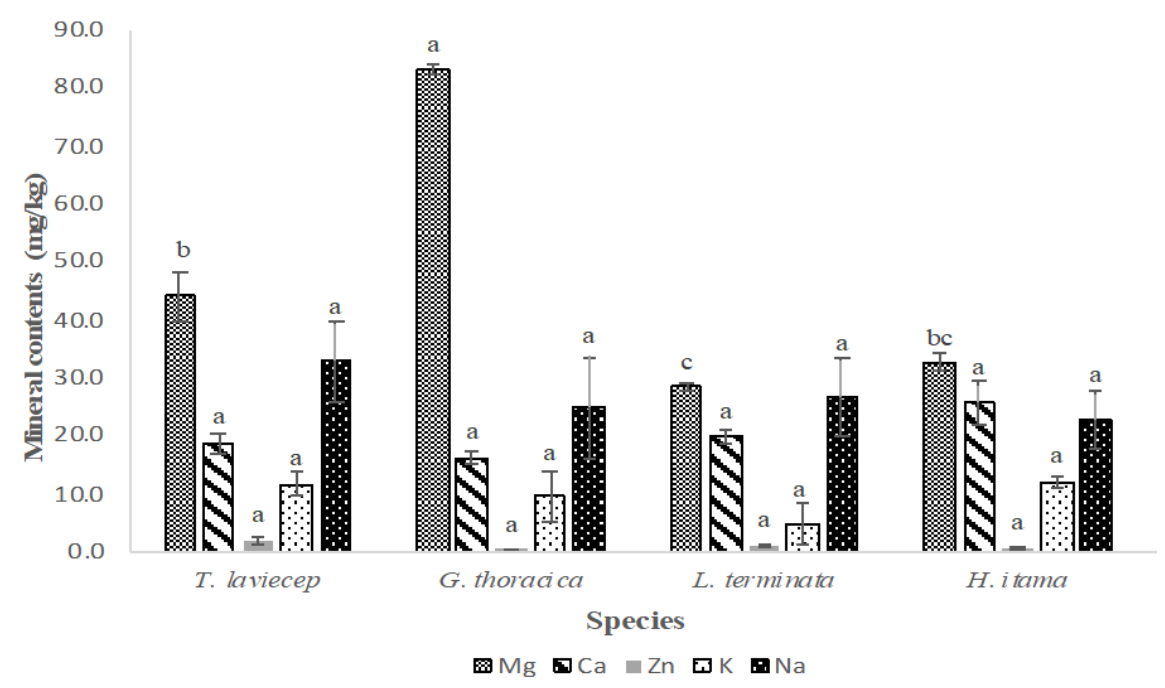

Figure 1. Mineral elements in four different species of stingless bee honey. Numbers are the mean \pm standard errors of four replications. Bars with the same letters above are not significantly different at $\mathrm{P} \leq 0.05$ by using Tukey test. 
overall total average of $\mathrm{Ca}$ elements in four stingless bee honey species was $80.49 \mathrm{mg} / \mathrm{kg}$. Honey that produced by $H$. itama possessed the highest in $\mathrm{Ca}(25.74 \mathrm{mg} / \mathrm{kg})$ followed by L. terminata $(19.83 \mathrm{mg} / \mathrm{kg}), T$. laeviceps $(18.73 \mathrm{mg} / \mathrm{kg})$, and lastly $G$. thoracica $(16.19 \mathrm{mg} / \mathrm{kg})$. Meanwhile, the element of Potassium (K) obtained the fourth abundant mineral in all honey samples. The study indicated that honey being produced by $H$. itama had the highest in $\mathrm{K}(12.08 \mathrm{mg} / \mathrm{kg})$ followed by $T$. laeviceps $(11.64 \mathrm{mg} / \mathrm{kg})$, G. thoracica $(9.67 \mathrm{mg} / \mathrm{kg})$, and lastly $L$. terminata $(4.78 \mathrm{mg} / \mathrm{kg})$.

Zinc $(\mathrm{Zn})$ is detected as a minor element that is fewer than $4 \mathrm{mg} / \mathrm{kg}$ that was found in all honey samples. It can be noted that honey from the $T$. laeviceps revealed the highest in $\mathrm{Zn}$ value $(2.07 \mathrm{mg} / \mathrm{kg})$ followed by $L$. terminata $(0.89 \mathrm{mg} / \mathrm{kg}), H$. itama $(0.65 \mathrm{mg} / \mathrm{kg})$, and lastly $G$. thoracica $(0.38 \mathrm{mg} / \mathrm{kg})$. The ANOVA analysis also indicated that the element of $\mathrm{Na}, \mathrm{Ca}, \mathrm{K}$, and $\mathrm{Zn}$ have no statistically significant difference between all the species of stingless bee. However, the element of $\mathrm{Mg}$ possessed statistically significant difference with all stingless bee species except for H. itama.

\section{Conclusion}

The recent study showed that the TPC and TFC, colour intensity, antioxidant activity, $\mathrm{pH}$, and the mineral elements of stingless bee honey can be elucidated by the natural disparities of the stingless bee species and the geographical location. This study has shown that different species of stingless bee resulted in different variation in phytochemical properties and mineral elements of honey. The evidence from this study also suggested that the differences in species were not sufficient enough to represent the statistically significant difference in phytochemical content and mineral elements of stingless bee honey. Different geographical location should be considered to obtain a more accurate finding on the phytochemical and mineral elements of the stingless bee honey. Future investigation and experiment into phytochemical, mineral elements and heavy metal of different species of stingless bee honey at different geographical regions in Malaysia is strongly recommended. This result can deliver a good database for establishing and identifying the international standard of stingless bee honey. The outcomes may also yield crucial data pertaining to stingless bee honey which could be referred to for future studies.

\section{Conflict of interest}

The authors have no competing interests to disclose.

\section{Acknowledgments}

The authors are thankful to Universiti Putra Malaysia for providing financial support under the Geran Putra research funding (GP-IPS/9633300).

\section{References}

Abu Bakar, M.F., Sanusi, S.B., Abu Bakar, F.I., Cong, O.J. and Mian, Z. (2017). Physicochemical and antioxidant potential of raw unprocessed honey from Malaysian stingless bees. Pakistan Journal of Nutrition, 16(11), 888-894. https://doi.org/10.3923/ pjn.2017.888.894

Agus, A., Agussalim, Nurliyani, Umami, N. and Budisatria, I.G.S. (2019). Evaluation of antioxidant activity, phenolic, flavonoid and vitamin $\mathrm{C}$ content of several honeys produced by the Indonesian stingless bee: Tetragonula laeviceps. Livestock Research for Rural Development, 31, 152.

Ali, F., Ranneh, Y., Ismail, A. and Esa, N.M. (2015). Identification of phenolic compounds in polyphenols rich extract of Malaysian cocoa powder using the HPLC-UV-ESI-MS/ MS and probing their antioxidant properties. Journal of Food Science and Technology, 52, 2103-2111. https://doi.org/10.1007/ s13197-013-1187-4

Alqarni, A.S., Owayss, A.A., Mahmoud, A.A. and Hannan, M.A. (2014). Mineral content and physical properties of local and imported honeys. Saudi Arabia. Journal of Saudi Chemical Society, 18(5), 618-625. https://doi.org/10.1016/j.jscs.2012.11.009

Alves, A., Ramos, A., Gonçalves, M.M., Bernardo, M. and Mendes, B. (2013). Antioxidant activity, quality parameters and mineral content of Portuguese monofloral honeys. Journal of Food Composition and Analysis, 30(2), 130-138. https:// doi.org/10.1016/j.jfca.2013.02.009

Ahmad, R. and Abdullah, N. (2013). Antioxidant Principles and In Vitro Evaluation Methods, p. 1-33. Malaysia: UiTM Press.

Bertoncelj, J., Dobersek, U., Jamnik, M. and Golob, T. (2007). Evaluation of the phenolic content, antioxidant activity and colour of Slovenian honey. Food Chemistry, 105(2), 822-828. https:// doi.org/10.1016/j.foodchem.2007.01.060

Beretta, G., Granata, P., Ferrero, M., Orioli, M. and Facino, R.M. (2005). Standardization of antioxidant properties of honey by a combination of spectrophotometric/fluorimetric assays and chemometrics. Analytica Chimica Acta, 533(2), 185191. https://doi.org/10.1016/j.aca.2004.11.010

Biluca, F.C., Braghini, F., Gonzaga, L. V., Costa, A.C.O. 
and Fett, R. (2016). Physicochemical profiles, minerals and bioactive compounds of stingless bee honey (Meliponinae). Journal of Food Composition and Analysis, 50, 61-69. https://doi.org/10.1016/ j.jfca.2016.05.007

Biluca, F.C., Braghini, F., Gonzaga, L.V., Pereira, L.M., Costa, A.C.O. and Fett, R. (2014). 5-HMF and carbohydrates content in stingless bee honey by $\mathrm{CE}$ before and after thermal treatment. Food Chemistry, 159, 244-249. https://doi.org/10.1016/ j.foodchem.2014.03.016

Boussaid, A., Chouaibi, M., Rezig, L., Hellal, R., Donsì, F., Ferrari, G. and Hamdi, S. (2014). Physicochemical and bioactive properties of six honey samples from various floral origins from Tunisia. Arabian Journal of Chemistry, 11(2), 265274. https://doi.org/10.1016/j.arabjc.2014.08.011

Cantarelli, M.A., Pellerano, R.G., Marchevsky, E.J. and Camiña, J.M. (2008). Quality of honey from Argentina: Study of chemical composition and trace elements. Journal of the Argentine Chemical Society, 12, 0365-0375. http://hdl.handle.net/11336/81719

Chuttong, B., Chanbang, Y., Sringarm, K. and Burgett, M. (2016). Physicochemical profiles of stingless bee (Apidae: Meliponini) honey from South East Asia (Thailand). Food Chemistry, 192, 149-155. https:// doi.org/10.1016/j.foodchem.2015.06.089

Codex Alimentarius Commission, (2001). Alinorm 41/10: revised standard for honey. Alinorm 1, 19-26.

Da Silva, I.A.A., Da Silva, T.M.S., Camara, C.A., Queiroz, N., Magnane, M. and De Novais, J.S. (2013). Phenolic profile, antioxidant activity and palynological analysis of stingless bee honey from Amazonas, Northern Brazil. Food Chemistry, 141 (4), 3552-3558. https://doi.org/10.1016/ j.foodchem.2013.06.072

De Sousa, J.M., Souza, E., Marques, G., De Toledo Benassi, M., Gullón, B., Pintado, M.M. and Magnani, M. (2016). Sugar profile: physicochemical and sensory aspects of monofloral honeys produced by different stingless bee species in Brazilian semiarid region. LWT-Food Science and Technology, 65, 645-651. https://doi.org/10.1016/j.lwt.2015.08.058

Fadzilah, N.H., Jaapar, M.F., Jajuli, R. and Omar, W.A.W. (2017). Total phenolic content, total flavonoid and antioxidant activity of ethanolic bee pollen extracts from three species of Malaysian stingless bee. Journal of Apicultural Research, 56 (2), 130-135. https:// doi.org/10.1080/00218839.2017.1287996

Finola, M.S., Lasagno, M.C. and Marioli, J.M. (2007). Microbiological and chemical characterization of honeys from central Argentina. Food Chemistry, 100 (4), 1649-1653. https://doi.org/10.1016/ j.foodchem.2005.12.046

Fuenmayor, C.A., Díaz-Moreno, A.C., ZuluagaDomínguez, C.M. and Quicazán, M.C. (2013). Honey of Colombian stingless bees: nutritional characteristics and physicochemical quality indicators. In Vit, P., Pedro, S. and Roubik, D. (eds) Pot-honey: A legacy of stingless bees, p. 383-394. New York, USA: Springer. https:// doi.org/10.1007/978-1-4614-4960-7_27

Garcia, E.J., Oldoni, T.L.C., Alencar, S.M., Reis, A., Loguercio, A.D. and Grande, R.H.M. (2012). Antioxidant activity by DPPH assay of potential solutions to be applied on bleached teeth. Brazil Dental Journal, 23, 22-27. https://doi.org/10.1590/ S0103-64402012000100004

Guerrini, A., Bruni, R., Maietti, S., Poli, F., Rossi, D., Paganetto, G., Muzzoli, M., Scalvenzi, L. and Sacchetti, G. (2009). Ecuadorian stingless bee (Meliponinae) honey: A chemical and functional profile of an ancient health product. Food Chemistry, 114(4), 1413-1420. https://doi.org/10.1016/ j.foodchem.2008.11.023

Habib, H.M., Al Meqbali, F.T., Kamal, H., Souka, U.D. and Ibrahim, W.H. (2014). Physicochemical and biochemical properties of honeys from arid regions. Food Chemistry, 153, 35-43. https://doi.org/10.1016/ j.foodchem.2013.12.048

Kek, S.P., Chin, N.L., Yusof, Y.A., Tan, S.W and Chua, L.S. (2017). Classification of entomological origin of honey based on its physicochemical and antioxidant properties. International Journal of Food Properties, 20(Suppl. 3), S2723-S2738. https:// doi.org/10.1080/10942912.2017.1359185

Kek, S.P., Chin, N.L., Yusof, Y.A., Tan, S.W. and Chua, L.S. (2014). Total phenolic contents and colour intensity of Malaysian honeys from the Apis spp. and Trigona spp. bees. Agriculture and Agricultural Science Procedia, 2, 150-155. https:// doi.org/10.1016/j.aaspro.2014.11.022

Kelly, N., Farisya, M. S. N., Kumara, T.K. and Marcela, P. (2014). Species diversity and external nest characteristics of stingless bees in meliponiculture. Pertanika Journal of Tropical Agricultural Science, 37, 293-298. http://www.pertanika.upm.edu.my/ index.php

Lim, D.C.C., Abu Bakar, M.F. and Majid, M. (2019). Nutritional composition of stingless bee honey from different botanical origins. IOP Conference Series: Earth and Environmental Science, 269, 012025. https://iopscience.iop.org/article/10.1088/17551315/269/1/012025/meta 
Maringgal, B., Hashim, N., Tawakkal, I.S.M.A., Mohamed, M.T.M. and Shukor, N.I.A. (2019). Phytochemical compositions and antioxidant activities of Malaysian stingless bee honey. Pertanika Journal of Science and Technology, 27 (S1), 15-28. http://www.pertanika.upm.edu.my/ index.php

Majid, M., Abu Bakar, M.F. and Mian, Z. (2019). Determination of xanthine oxidase inhibition in stingless bee honey from different botanical origin. IOP Conference Series: Earth and Environmental Science, 269, 012029. https://iopscience.iop.org/ article/10.1088/1755-1315/269/1/012029/meta

Malaysian Standards, (2017). Kelulut (Stingless Bee) honey-Specification. MS 2683. Malaysia.

Mohd Nasir, N., Mohd, K.S., Ibrahim, N., Mohd Rodi, M.M. and Zakaria, A.J. (2019). Physicochemical analysis and antioxidant activity of honey from three Malaysian stingless bees species. Journal of Agrobiotechnology, 10, 1-11. https:// journal.unisza.edu.my/agrobiotechnology/index.php/ agrobiotechnology/article/view/203

Nordin, A., Sainik, N.Q.A.V., Chowdhury, S.R., Saim, A.B. and Idrus, R.B.H. (2018). Physicochemical properties of stingless bee honey from around the globe: A comprehensive review. Journal of Food Composition and Analysis, 73, 91-102. https:// doi.org/10.1016/j.jfca.2018.06.002

Norowi, M.H., Sajap, A.S., Rosliza, J., Fahimie, M.J. and Suri, R. (2010). Conservation and sustainable utilization of stingless bees for pollination services in agricultural ecosystems in Malaysia presented at the Proceeding of International Seminar on Enhancement of Functional Biodiversity Relevant to Sustainable Food Production in ASPAC. Tsukuba, Japan.

Omar, S., Enchang, F.K., Nazri, M.U.I.A., Ismail, M.M. and Ismail, W.I.W. (2019). Physicochemical profiles of honey harvested from four major species of stingless bee (Kelulut) in north east peninsular of Malaysia. Malaysian Applied Biology Journal, 48 (1), 111-116. http:// journalarticle.ukm.my/12785/1/48_01_16.pdf

Pohl, P. (2009). Determination of metal content in honey by atomic absorption and emission spectrometries. TrAC Trends in Analytical Chemistry, 28(1), 117128. https://doi.org/10.1016/j.trac.2008.09.015

Ramón-Sierra, J.M., Ruiz-Ruiz, J.C. and Ortiz-Vázquez, E.L. (2015). Electrophoresis characterisation of protein as a method to establish the entomological origin of stingless bee honeys. Food Chemistry, 183, 43-48. https://doi.org/10.1016/
Rodriguez-Malaver, Vit, P., Pedro, S.R.M. and Roubik, D. (2013). Antioxidant activity of pot honey. In Vit, P., Pedro, S. and Roubik, D. (eds) Pot-honey: A legacy of stingless bees, p. 475-480. New York, USA: Springer. https://doi.org/10.1007/978-1-46144960-7_34

Rodriguez-Malaver, A.J., Rasmussen, C., Gutierrez, M.G., Gil, F., Nieves, B. and Vit, P. (2009). Properties of honey from ten species of Peruvian stingless bees. Natural Product Communications, 4 (9), 1221-1226. https://doi.org/10.1177\% 2F1934578X0900400913

Shadan, A.F., Mahat, N.A., Wan Ibrahim, W.A., Ariffin, Z. and Ismail, D. (2018). Provenance establishment of stingless bee honey using multi element analysis in combination with chemometrics techniques. Journal of Forensic Sciences, 63(1), 1-6. https:// doi.org/10.1111/1556-4029.13512

Silva, T.M.S., Dos Santos, F.P., Evangelista-Rodrigues, A., Da Silva, E.M.S., Da Silva, G.S., De Novais, J.S., Dos Santos, F.D.A.R. and Camara, C.A. (2013). Phenolic compounds, melissopalynological: physicochemical analysis and antioxidant activity of jandaíra (Melipona subnitida) honey. Journal of Food Composition Analysis, 29(1), 10-18. https:// doi.org/10.1016/j.jfca.2012.08.010

Suntiparapop, K., Prapaipong, P. and Chantawannakul, P. (2012). Chemical and biological properties of honey from Thai stingless bee (Tetragonula leaviceps). Journal of Apicultural Research, 51(1), 45-52. https://doi.org/10.3896/IBRA.1.51.1.06

Tuksitha, L., Chen, Y., Chen, Y., Wong, K. and Peng, C. (2018). Antioxidant and antibacterial capacity of stingless bee honey from Borneo (Sarawak). Journal Asia Pacific. Entomology, 21(2), 563-570. https:// doi.org/10.1016/j.aspen.2018.03.007

Yen, G.C. and Duh, P.D. (1993). Antioxidative properties of methanolic extracts from peanut hulls. Journal of the American Oil Chemists Society, 70(4), 383-386. https://doi.org/10.1007/BF02552711 